\title{
NRF2 Is a Potential Modulator of Hyperresistance to Arsenic Toxicity in Stem-Like Keratinocytes
}

\author{
Xiafang Wu, ${ }^{1}$ Bei Yang, ${ }^{2}$ Yuxin Hu, ${ }^{3}$ Ru Sun, ${ }^{1}$ Huihui Wang, ${ }^{1}$ Jingqi Fu, ${ }^{1}$ Yongyong Hou, ${ }^{1}$ \\ Jingbo $\mathrm{Pi}^{1,3}$ and Yuanyuan $\mathrm{Xu}^{1,3}$ \\ ${ }^{1}$ Program of Environmental Toxicology, School of Public Health, China Medical University, Shenyang, Liaoning, China \\ ${ }^{2}$ Department of Histology and Embryology, College of Basic Medical Sciences, China Medical University, Shenyang, Liaoning, China \\ ${ }^{3}$ Experimental Teaching Center, School of Public Health, China Medical University, Shenyang, Liaoning, China
}

Correspondence should be addressed to Yuanyuan Xu; yyxu@cmu.edu.cn

Received 20 January 2017; Revised 7 July 2017; Accepted 1 August 2017; Published 10 September 2017

Academic Editor: Kum Kum Khanna

Copyright (c) 2017 Xiafang Wu et al. This is an open access article distributed under the Creative Commons Attribution License, which permits unrestricted use, distribution, and reproduction in any medium, provided the original work is properly cited.

\begin{abstract}
Arsenic is a well-known human carcinogen. Stem cells are indicated to be involved in arsenic carcinogenesis and have a survival selection advantage during arsenic exposure with underlying mechanisms undefined. In the present study, we demonstrated that $\mathrm{CD} 34^{\text {high }}$-enriched cells derived from HaCaT human keratinocytes showed stem-like phenotypes. These cells were more resistant to arsenic toxicity and had higher arsenic efflux ability than their mature compartments. The master transcription factor in antioxidant defense, nuclear factor erythroid 2-related factor 2 (NRF2) with its downstream genes, was highly expressed in CD34 ${ }^{\text {high }}$-enriched cells. Stable knockdown of NRF2 abolished the hyperresistance to arsenic toxicity and holoclone-forming ability of $\mathrm{CD} 34^{\text {high }}$-enriched cells. Our results suggest that skin epithelial stem/progenitor cells are more resistant to arsenic toxicity than mature cells, which is associated with the high innate expression of NRF2 in skin epithelial stem/progenitor cells.
\end{abstract}

\section{Introduction}

Arsenic is naturally distributed in the environment as a component of water and soil and is also a contaminating metalloid dispersed by human activity [1]. Although arsenic has been identified as a human carcinogen with the skin as one of the targets [2], its carcinogenic mechanisms remain elusive. Transplacental carcinogenic activity of arsenic observed in humans $[3,4]$ and in experimental mouse models $[5,6]$ suggests that the fetal stem cell is a key target during carcinogenesis of this metalloid. Chronic exposure to arsenic has been shown to induce overabundance of stem cells or cancer stem cells during malignant transformation in various human cell lines [7-9], indicating a stem cell survival selection advantage in response to arsenic toxicity regardless of the tissue origin. With respect to the skin, in vitro models observed that short-term arsenic exposure maintained epidermal cells in a geminative state, blocking differentiation of the putative stem/progenitor cells [10]; chronic arsenic exposure induced an elevation in CD34-positive stem-like cancer cells during the process of malignant transformation of $\mathrm{HaCaT}$ cells [7]. In vivo study observed that in utero exposure to arsenite in mice led to disrupted homeostasis of skin stem cell [11] and increased risk of skin tumors with an accumulation of skin cancer stem cells as marked by CD34 [5]. However, no direct evidence for the effect of arsenic on skin stem cells is available.

Arsenic is a well-known oxidative stressor. As a master regulator of cellular antioxidant system [12], nuclear factor erythroid 2-related factor 2 (NRF2) is closely related to arsenic toxicity [13-16]. NRF2 regulates expression of downstream genes through the antioxidant response element (ARE) [17]. These downstream genes encode (1) antioxidant enzymes such as $\gamma$-glutamate cysteine ligase catalytic subunit (GCLC) and regulatory subunit (GCLM), (2) phase II drugmetabolizing enzymes such as heme oxygenase 1 (HMOX1) and $\mathrm{NAD}(\mathrm{P}) \mathrm{H}$ quinone oxidoreductase 1 (NQO1), and (3) multidrug-resistant proteins (MRPs) such as ATP-binding 
cassette subfamily (ABC) C1 (ABCC1), ABCC2, ABCC3, and ABCG2 [18-20]. Therefore, activation of NRF2-ARE pathway contributes to cellular defense and poses a survival advantage for cells in response to arsenic exposure $[13,16]$. Supporting this theory, Nrf2-knockout mice are highly susceptible to oxidative damage or chemical carcinogenesis compared with the wild-type littermates [21, 22]. On the other hand, constitutive activation of NRF2 is suggested to result in a cancer phenotype [23], including in arsenicinduced malignant transformation of human keratinocytes [14], and moreover facilitate chemo- and radioresistance of cancer cells $[24,25]$.

Considering the observed overabundance of stem cells after arsenic exposure and the active role of NRF2 in chemical resistance [24-27], it is reasonable to assume that NRF2 is involved in stem cell biology and stem cell response to arsenic. Previous studies indicate that NRF2 regulates stem cell maintenance and differentiation; however, the reports are not consistent. For example, a reduction of high NRF2 activity induced cell differentiation and inhibited pluripotency in human embryonic stem cells (hESCs) [28], whereas in muscle and neural stem/progenitor cells, more evidence supported that NRF2 was not highly expressed or activated until proliferation or differentiation occurred and therefore played roles in tissue regeneration $[29,30]$. It appears that the function of NRF2 in homeostasis of stem cells depends on cell types and specific physical/pathological conditions. The role of NRF2 in stem cells, especially when they are under insult or stress, requires to be further elucidated.

CD34 is a surface marker for stem cells and cancer stem cells in the skin $[31,32]$. In the present study, CD $34^{\text {high }}$ enriched cells isolated from $\mathrm{HaCaT}$ human keratinocytes showed stem-like phenotypes and were used as a stem/progenitor cell model. Then, we tested our hypothesis that skin stem/progenitor cells possess a survival selection advantage in response to arsenic exposure. Furthermore, we found that NRF2 was more active in these stem/progenitor cells compared with the mature compartments and contributed to the hyperresistance to arsenic toxicity in these stem/ progenitor cells.

\section{Material and Methods}

2.1. Cell Culture and Treatment. HaCaT human keratinocytes were obtained from the Shanghai Institute of Biochemistry and Cell Biology, Chinese Academy of Sciences (Shanghai, China). Cells were grown in DMEM medium (C11995500BT, GIBCO, Beijing, China) supplemented with $10 \%$ fetal bovine serum (FBS) (04-00101-A, Biological Industries, Cromwell, CT) and 1\% pen-strep solution (03-031-1B, Biological Industries) under a humidified atmosphere of $5 \% \mathrm{CO}_{2}$ and $95 \%$ air at $37^{\circ} \mathrm{C}$. CD $34^{\text {high }}$-enriched cells, $\mathrm{CD} 34^{\text {low }}$-expressing cells, and passage-matched $\mathrm{HaCaT}$ (parent) cells were cultured on type IV collagen (3410-01001, Trevigen, Gaithersburg, MD) and fibronectin-coated (610077, BD Biosciences, Bedford, MD) culture dish (or flask). Cells were maintained in EpiLife medium (MEPI500CA, Invitrogen, Shanghai, China) containing $5 \mathrm{ml}$ of human keratinocyte growth supplement (S0015, Invitrogen) and 1\% pen-strep solution. Cells at $80 \%$ confluence were exposed to sodium arsenite (S7400, Sigma, St. Louis, MO) as indicated.

2.2. Magnetic-Activated Cell Sorting (MACS). MACS was performed with Mini MACS Starting Kit (130-042-301, Miltenyi, Auburn, CA) according to the instruction of the manufacturer. Cultured cells were trypsinized, resuspended in MACS buffer [calcium- and magnesium-free phosphatebuffered saline (PBS) containing $0.5 \%$ bovine serum albumin (BSA) and $2 \mathrm{mM}$ ethylene diamine tetraacetic acid (EDTA)] at a concentration of $5 \times 10^{7}$ cells $/ 300 \mu \mathrm{l}$, and incubated with FcR blocking reagent and CD34 microbeads (130-046-702, Miltenyi) for $30 \mathrm{~min}$ at $4^{\circ} \mathrm{C}$. After washings, cells were passed through $30 \mu \mathrm{M}$ preseparation filter. CD $34^{\text {high }}$-enriched cells were separated by positive selection on LS column (130042-401, Miltenyi). Flow-through from positive selection was collected for CD $34^{\text {low }}$-expressing cells.

2.3. Quantification of CD34 $4^{\text {high }}$ Population with Flow Cytometry. Cells were detached by trypsinization, washed once with PBS, and counted. $5 \times 10^{5}$ cells were suspended in $100 \mu \mathrm{l}$ MACS buffer, incubated with $20 \%$ phycoerythrin (PE) anti-human CD34 antibody (A07776, Beckman Coulter, France) or isotype control (A07796, Beckman Coulter) for $20 \mathrm{~min}$ at room temperature (RT) in dark, washed with $1 \mathrm{ml}$ ice-cold MACS buffer, and centrifuged $(300 \times \mathrm{g})$ for $5 \mathrm{~min}$ at $4^{\circ} \mathrm{C}$. Cells resuspended in $0.5 \mathrm{ml} \mathrm{PBS}$ were determined using a Canto II flow cytometer (Becton-Dickinson, San Jose, CA) and analyzed by CellQuest software (BectonDickinson) or FlowJo (FlowJo, LLC).

2.4. Cell Viability. Cells were seeded in the 96-well plate at a density of $1.5 \times 10^{4}$ cells per well and incubated at $37^{\circ} \mathrm{C}$ with $5 \% \mathrm{CO}_{2}$ overnight. After treated with sodium arsenite at indicated concentrations for $24 \mathrm{~h}$, cell viability was assayed using a CellTiter 96 AQueous One Solution Cell Proliferation Assay (MTS) Kit (Promega, Madison, WI) according to the manufacturer's instruction. This method measures the production of formazan catalyzed by mitochondrial dehydrogenase of viable cells. Formazan production was measured at a wavelength of $490 \mathrm{~nm}$ using a Synergy $\mathrm{H} 1$ microplate reader (Biotek, Vermont, USA).

2.5. Apoptosis Detected by Flow Cytometry. $8 \times 10^{5}$ cells per well were plated in the 6-well plate and allowed to attach overnight. Then, cells were treated with $20 \mu \mathrm{M}$ or $40 \mu \mathrm{M}$ sodium arsenite for $24 \mathrm{~h}$, harvested with trypsinization, and centrifuged at $300 \times \mathrm{g}$ for $5 \mathrm{~min}$. Apoptosis was detected with TACS Annexin V Kit (4830-250-K, Trevigen) according to the manufacturer's protocol. Annexin V-FITC and propidium iodide- (PI-) staining cells were quantified with Canto II flow cytometer (Becton-Dickinson) equipped with CellQuest software (Becton-Dickinson).

2.6. Holoclone Formation. Holoclones are considered to be enriched in stem-like cells [33]. CD $34^{\text {high }}$-enriched, CD34 ${ }^{\text {low }}$-expressing, and parent cells were trypsinized, filtered with $70 \mu \mathrm{m}$ cell strainer, counted, and plated in the 6-well plate $\left(2 \times 10^{3}\right.$ cells/well). The number of holoclones was counted 
under inverted microscope (DMI-LED, Leica, China) after 2 weeks.

\subsection{Reverse Transcriptase Quantitative Polymerase Chain} Reaction (RT-qPCR). RT-qPCR was performed as previously described [9]. Briefly, total RNA was isolated using TRIzol reagent (Invitrogen, Carlsbad, CA), purified with RNeasy mini kit columns (Qiagen, Valencia, CA), and reverse transcribed to cDNA using Prime Script RT reagent kit (TaKaRa, Dalian, China). SYBR Premix Ex Taq Kit (TaKaRa) was used to assess cDNA amplifications. Data were analyzed using the delta-delta cycle time method. All primers were designed with Primer-BLAST online (http://www.ncbi.nlm.nih.gov/ tools/primer-blast) and obtained from Sigma-Aldrich. Primer sequences are provided in supplemental material Table S1 available online at https://doi.org/10.1155/2017/ 7417694.

2.8. Western Blot. Protein isolation from whole-cell lysates was performed by using cell lysis buffer (Cell Signaling Technology, Danvers, MA) with $0.5 \%$ protease inhibitor cocktail (P8340, Sigma-Aldrich), 1\% phosphatase inhibitor cocktail 2 (P5726, Sigma-Aldrich), and 1\% phosphatase inhibitor cocktail 3 (P004, Sigma-Aldrich) on ice for $30 \mathrm{~min}$. Protein extracts were separated by $7.5 \%$ SDS-polyacrylamide gel electrophoresis and transferred to polyvinylidene fluoride (PVDF) membranes (Millipore, Bedford, MA). The membranes were blocked with 5\% nonfat milk and immunoblotted with primary antibody of p63 (20697-1-AP, Proteintech, Wuhan, China), OCT4 (11263-1-AP, Proteintech), keratin 5 (K5, Ab52635, Abcam, US), keratin 14 (K14, 10143-1-AP, Proteintech), SHH (20697-1-AP, Proteintech), NRF2 (sc-13032, Santa Cruz Biotechnology, Santa Cruz, CA), or $\beta$-actin (sc-69879, Santa Cruz Biotechnology) overnight at $4^{\circ} \mathrm{C}$ and with secondary antibodies (Santa Cruz Biotechnology) for $1 \mathrm{~h}$ at RT. Protein bands were detected with the Chemistar ECL Western Blotting Substrate (180-5001, Tanon, Shanghai, China), and the image was captured by 5500 Automatic Chemiluminescence Imaging System (Tanon).

2.9. Intracellular ROS. Intracellular ROS levels were evaluated by measuring dichlorofluorescein (DCF) fluorescence as described previously [34]. Briefly, cells were seeded in 12-well plates and treated with vehicle (Veh.), $20 \mu \mathrm{M}$, or $40 \mu \mathrm{M}$ sodium arsenite for $2 \mathrm{~h}$. At the end of the treatment, cells were incubated with $2 \mu \mathrm{M}$ 5-(and-6)-chloromethyl$2^{\prime}, 7^{\prime}$-dichlorodihydrofluorescein diacetate and acetyl ester (CM-H2DCFDA) (Molecular Probes, Eugene, OR) for $30 \mathrm{~min}$ at $37^{\circ} \mathrm{C}$. The fluorescence was analyzed with Canto II flow cytometer $(\lambda$ exc $=488 \mathrm{~nm}, \lambda$ em $=525 \mathrm{~nm})$ (Becton-Dickinson).

2.10. Cellular Arsenic Accumulation and Export. Determination of cellular arsenic accumulation and export was modified from a previous report [35]. Cells were grown in arsenic-free medium to approximately $70 \%$ confluence. The medium was replaced with either fresh medium or medium containing $10 \mu \mathrm{M}$ sodium arsenite. After $24 \mathrm{~h}$, to determine arsenic accumulation, cells were washed three times with
PBS, harvested with trypsin, counted, and digested overnight with $50 \%$ perchloric acid: nitric acid $(2: 1)$ at $70^{\circ} \mathrm{C}$; to determine arsenic export, PBS-washed cells were incubated in fresh arsenic-free medium for another $24 \mathrm{~h}$. Then, medium was collected, and cells were trypsinized and counted. Arsenic concentration in the cell or medium was determined by graphite furnace atomic absorption spectrophotometry using a Perkin Elmer AAnalyst 100. Arsenic concentrations were normalized to cell number.

2.11. Silencing NRF2 by Lentiviral-Based shRNA Transduction. MISSION shRNA lentiviral particles were purchased from Sigma-Aldrich. Transduction of $\mathrm{HaCaT}$ cells with lentiviralbased shRNAs targeting NRF2 (SHVRS-NM_006164) or scrambled nontarget negative control (SHC002V) was performed as previously described [36]. Transducted cells were maintained in DMEM medium containing $1.0 \mu \mathrm{g} / \mathrm{ml}$ puromycin (Invitrogen).

2.12. Statistical Analysis. Data were analyzed with GraphPad Prism 5 (GraphPad Software, San Diego, CA) and presented as mean \pm standard deviation (SD). Unpaired Student's $t$ tests were used to compare the difference between Veh. and arsenic-exposed cells, as well as between scramble and NRF2-KD cells. Bonferroni posttests after one-way or twoway analysis of variance (ANOVA) were applied to other comparisons when it was appropriate. $p<0.05$ was considered significant. All the experiments were carried out at least in triplicate.

\section{Results}

3.1. Survival Potential of $\mathrm{CD} 34^{\text {high }}$ Subpopulation in HaCaT Cells in Response to Arsenic Exposure. CD34 is a surface marker for stem cells in the skin [31,32]. We first assessed the presence of the cells with high expression of CD34 surface marker in $\mathrm{HaCaT}$ cells with flow cytometry (Figure 1(a)). $\mathrm{CD} 34^{\text {high }}$ subpopulation is quite a small fraction, approximately $0.2-0.7 \%$ in HaCaT cells. After arsenic challenge (50 $\mu \mathrm{M}, 24 \mathrm{~h}), \mathrm{CD} 34^{\text {high }}$ subpopulation was markedly increased to $8.9-11.1 \%$ (Figure 1(b)). Stem cells are resistant to chemical insult and are suggested to act as a "strategic" adaption in arsenic carcinogenesis [27]. One possible explanation for the observed increase of $\mathrm{CD} 34^{\text {high }}$ subpopulation is the hyperresistance of $\mathrm{CD} 34^{\text {high }}$ cells to arsenic-induced cytotoxicity. We tested this idea in the following study.

3.2. Stem-Like Characteristics of CD34 $4^{\text {high }}$-Enriched Cells. Subsequently, CD $34^{\text {high }}$ fraction was separated by positive MACS sorting and a CD34 $4^{\text {high }}$-enriched population was obtained (Figure 2(a)). Markers for undifferentiated epithelial cells such as p63, K5, and K14 and those for stem cells such as CD34, OCT4, and $S H H$ were consistently expressed at higher mRNA levels and protein levels in CD34 $4^{\text {high }}$ enriched cells than $\mathrm{CD} 34^{\text {low }}$-expressing and parent cells (Figures 2(b) and 2(c)). Holoclone formation was used to indicate potential self-renewal characteristics of stem cell. Freshly isolated CD $34^{\text {high }}$-enriched cells formed more holoclones, which are large and round colonies with a smooth boundary mostly containing small cells, than $\mathrm{CD} 34^{\text {low }}$ - 


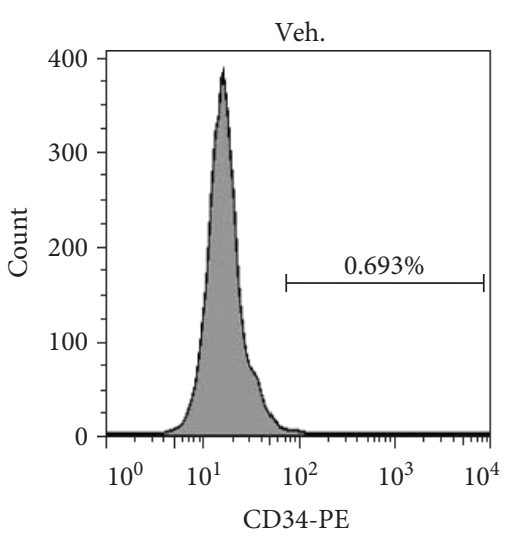

(a)
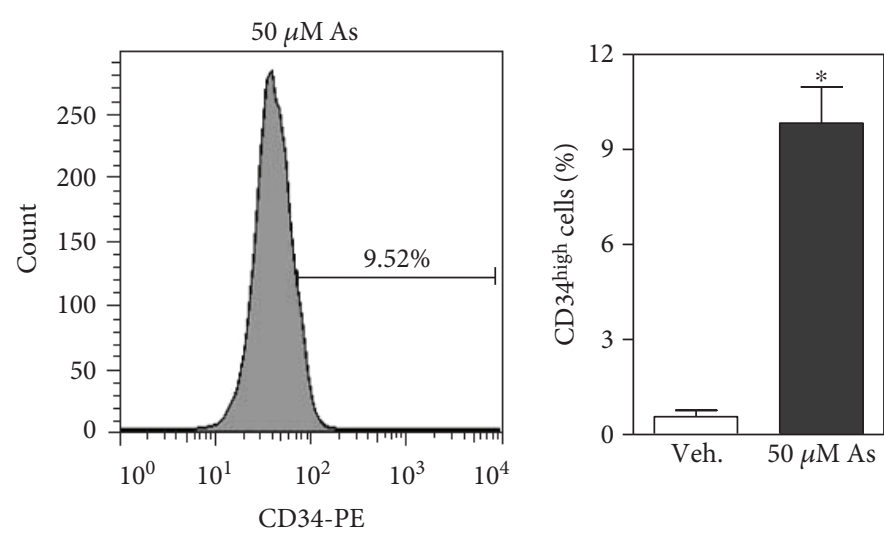

(b)

FIGURE 1: Flow cytometric analysis of the ratio of CD34-high-expressing (CD34 $4^{\text {high }}$ ) cells in HaCaT cells. (a) Representative histogram of flow cytometric analysis for $\mathrm{CD} 34^{\text {high }}$ cells. Left: HaCaT cells were exposed to vehicle (Veh., same volume of PBS to arsenic solution); right: HaCaT cells were exposed to $50 \mu \mathrm{M}$ sodium arsenite for $24 \mathrm{~h}$. (b) Quantification of CD34 ${ }^{\text {high }}$ population in HaCaT cells exposed to Veh. and arsenic. $1 \times 10^{5}$ cells were counted for each sample. $n=3 .{ }^{*} p<0.05$ compared with Veh.

expressing and parent cells in 2 weeks (Figure 2(d)). Moreover, holoclones formed by CD34 ${ }^{\text {high }}$-enriched cells appeared larger than those generated by $\mathrm{CD} 34^{\text {low }}$-expressing and parent cells (Figure 2(d)). Holoclones formed in all cell groups could be repeatedly subcultured and generate more holoclones. Though no specific in vitro assay can confirm the identity of stem cells, the above evidence supports that $\mathrm{CD} 34^{\text {high }}$-enriched subpopulation isolated from $\mathrm{HaCaT}$ cells exhibits stem-like phenotypes.

3.3. Increased Resistance of CD34 $4^{\text {high }}$-Enriched Cells to Arsenic Toxicity. To test cellular defense against arsenic toxicity, CD $34^{\text {high }}$-enriched cells, CD $34^{\text {low }}$-expressing cells, and parent cells were acutely $(24 \mathrm{~h})$ exposed to sodium arsenite. As shown in Figure 3(a), CD34 $4^{\text {high }}$-enriched cells showed significantly increased viability compared with $\mathrm{CD} 34^{\mathrm{low}}$-expressing and parent cells in response to arsenic from $20 \mu \mathrm{M}$ to $80 \mu \mathrm{M}$. The lethal concentration 50 (LC50) was $88.1 \mu \mathrm{M}$ for $\mathrm{CD} 34^{\text {high }}$-enriched cells, $58.8 \mu \mathrm{M}$ for $\mathrm{CD} 34^{\text {low }}$-expressing cells, and $56.7 \mu \mathrm{M}$ for parent cells. Then, arsenic-induced apoptosis was measured with Annexin V-FITC and PI double staining method. Consistent with the results of cell viability, less apoptotic cells were observed in high-level arsenic-exposed CD34 ${ }^{\text {high }}$ enriched cells compared with CD $34^{\text {low }}$-expressing and parent cells (Figures 3(b) and 3(c)).

3.4. High Activity of NRF2 and ROS Levels in CD $34^{\text {high }}$ Enriched Cells. Western blot showed higher innate and arsenic-induced NRF2 protein levels in CD $34^{\text {high }}$-enriched cells than CD $34^{\text {low }}$-expressing and parent cells (Figure 4(a)). Consistently, a panel of NRF2 downstream genes, including those encoding multidrug resistance proteins (MRPs) such as ABCG2 and ABCC1, and antioxidant enzymes HMOX1 and GCLC, was increased at the transcript level in CD34 ${ }^{\text {high }}$-enriched cells compared with CD $34^{\text {low }}$-expressing and parent cells (Figure 4(b)). The intracellular ROS levels in CD $34^{\text {high }}$-enriched cells were surprisingly higher than
CD34 $4^{\text {low }}$-expressing and parent cells under basal conditions (Figures 4(c) and 4(d)). Interestingly, ROS levels were increased to $1.5-2$ fold of Veh. in CD34 ${ }^{\text {low }}$-expressing and parent cells in response to arsenic, but remained stable in CD34 $4^{\text {high }}$-enriched cells (Figures 4(c) and 4(d)).

3.5. Increased Export of Arsenic from CD $34^{\text {high }}$-Enriched Cells. Some NRF2 downstream genes, including MRPs and GCLC, are involved in intracellular arsenic export, and their high expression may contribute to arsenic resistance [35]. Thus, we evaluated arsenic accumulation and export in CD34 ${ }^{\text {high }}$-enriched cells after acute arsenic exposure. CD $34^{\text {high }}$-enriched cells showed significantly lower intracellular arsenic levels than $\mathrm{CD} 34^{\text {low }}$-expressing cells after $24 \mathrm{~h}$ arsenic exposure (Figure 5(a)). The reduced intracellular arsenic accumulation may be caused by enhanced arsenic export. As shown in Figure 5(b), after acute exposure to the same level of arsenic, CD $34^{\text {high }}$ enriched cells eliminated more accumulated arsenic into the medium in the next $24 \mathrm{~h}$ compared with $\mathrm{CD} 34^{\text {low }}$ expressing and parent cells.

3.6. Abrogation of Hyperresistance to Arsenic Toxicity in CD $34^{\text {high }}$-Enriched Cells due to NRF2 Silencing. Since resistance to arsenic toxicity and increased cellular arsenic export of $\mathrm{CD} 34^{\text {high }}$-enriched cells can be attributed to high NRF2 activity, we subsequently examined what if NRF2 was silenced. NRF2-KD did not change the proportion of CD34 high cells in HaCaT cells (Figure 6(a)), suggesting that reduced NRF2 expression does not affect expression of CD34. CD34 $4^{\text {high }}$-enriched cells isolated from NRF2-KD cells showed significant decreases in NRF2 mRNA levels (Figure 6(b)), which were approximately $50 \%$ of scramble. Western blot showed that NRF2 protein expression was obviously reduced in NRF2-KD cells than scramble cells, especially when cells were treated with $20 \mu \mathrm{M}$ sodium arsenite (Figure 6(c)). Decreased cell viability in NRF2-KD CD34 $4_{\text {high }}$-enriched cells compared with 

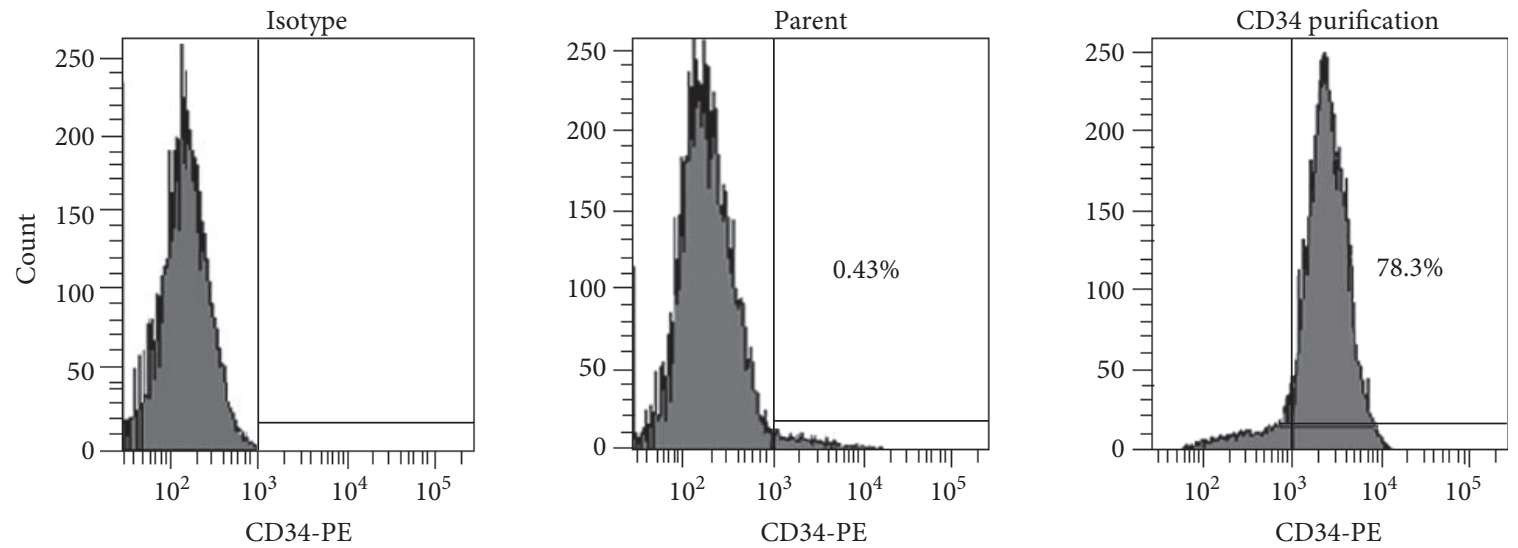

(a)

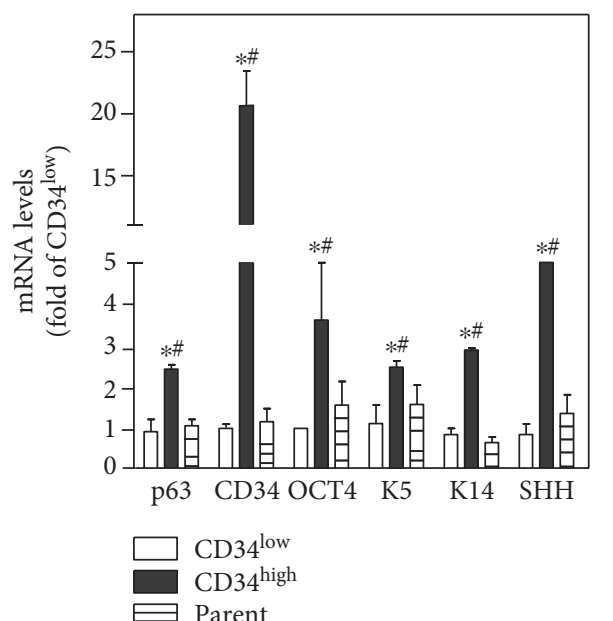

(b)

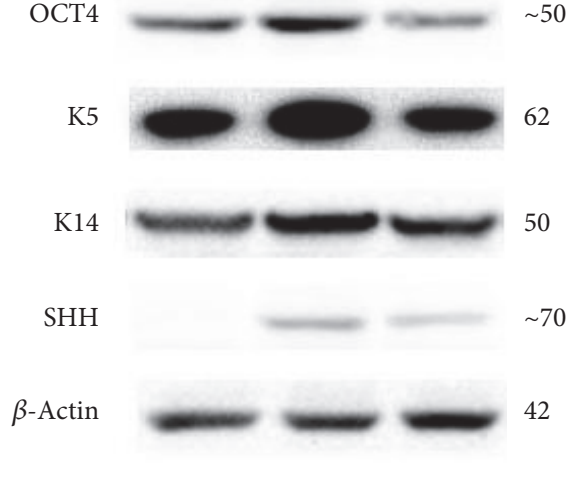

(c)
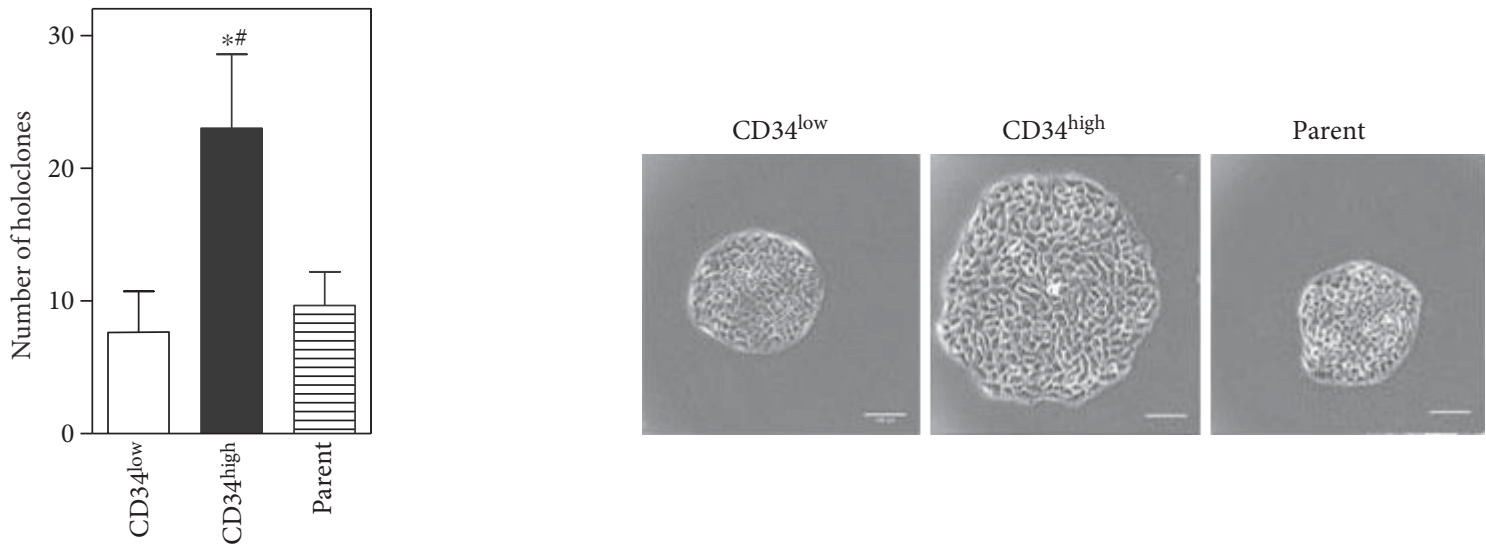

(d)

FIGURE 2: Stem-like characteristics of CD $34^{\text {high }}$-enriched cells. (a) Flow cytometric analysis of the ratio of CD34 $4^{\text {high }}$ cells. Left: isotope control of CD34 antibody; middle: the ratio of CD34 ${ }^{\text {high }}$ cells in the HaCaT (parent) cells; right: the ratio of CD34 ${ }^{\text {high }}$ cells after positive selection by CD34 magnetic beads. (b) mRNA and (c) protein levels of typical markers for undifferentiated epithelial cells or stem cells in CD34 ${ }^{\text {low }}$ expressing, CD $34^{\text {high }}$-enriched, and $\mathrm{HaCaT}$ (parent) cells. (d) Holoclone formation by CD $34^{\text {low }}$-expressing, $\mathrm{CD} 34^{\text {high }}$-enriched, and parent cells. Left: the number of holoclones was increased in CD34 $4^{\text {high }}$-enriched cells compared with the CD34 ${ }^{\text {low }}$-expressing or parent cells; right: representative image of holoclones $(400 \mathrm{x}$ magnification, bar $=100 \mu \mathrm{m}) . n=3 .{ }^{*} p<0.05$ compared with the CD34 ${ }^{\text {low }}$-expressing cells. ${ }^{\#} p<0.05$ compared with the parent cells. 

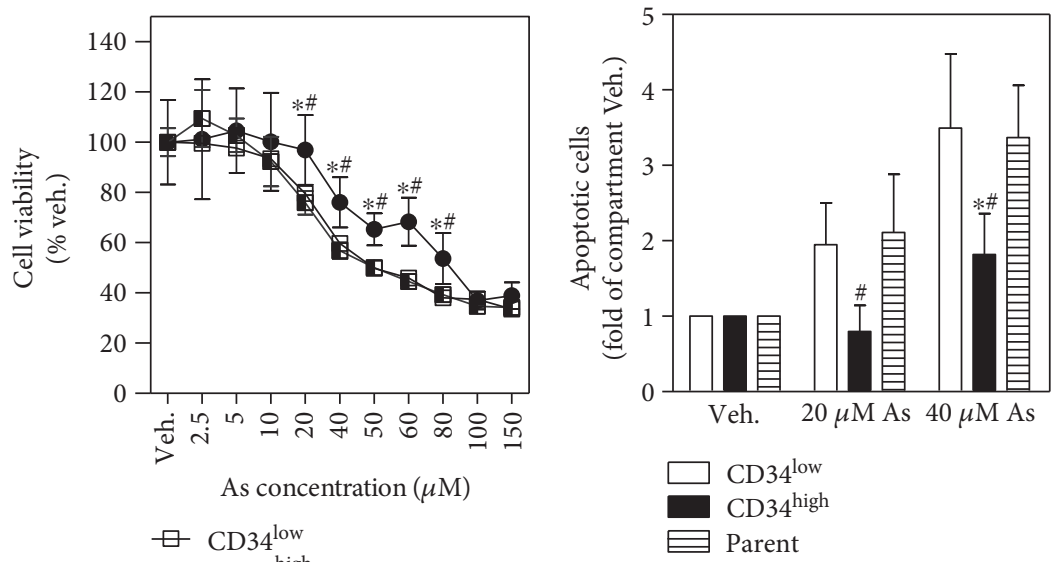

$\rightarrow \mathrm{CD} 34^{\text {high }}$

7- Parent

(a)

(b)
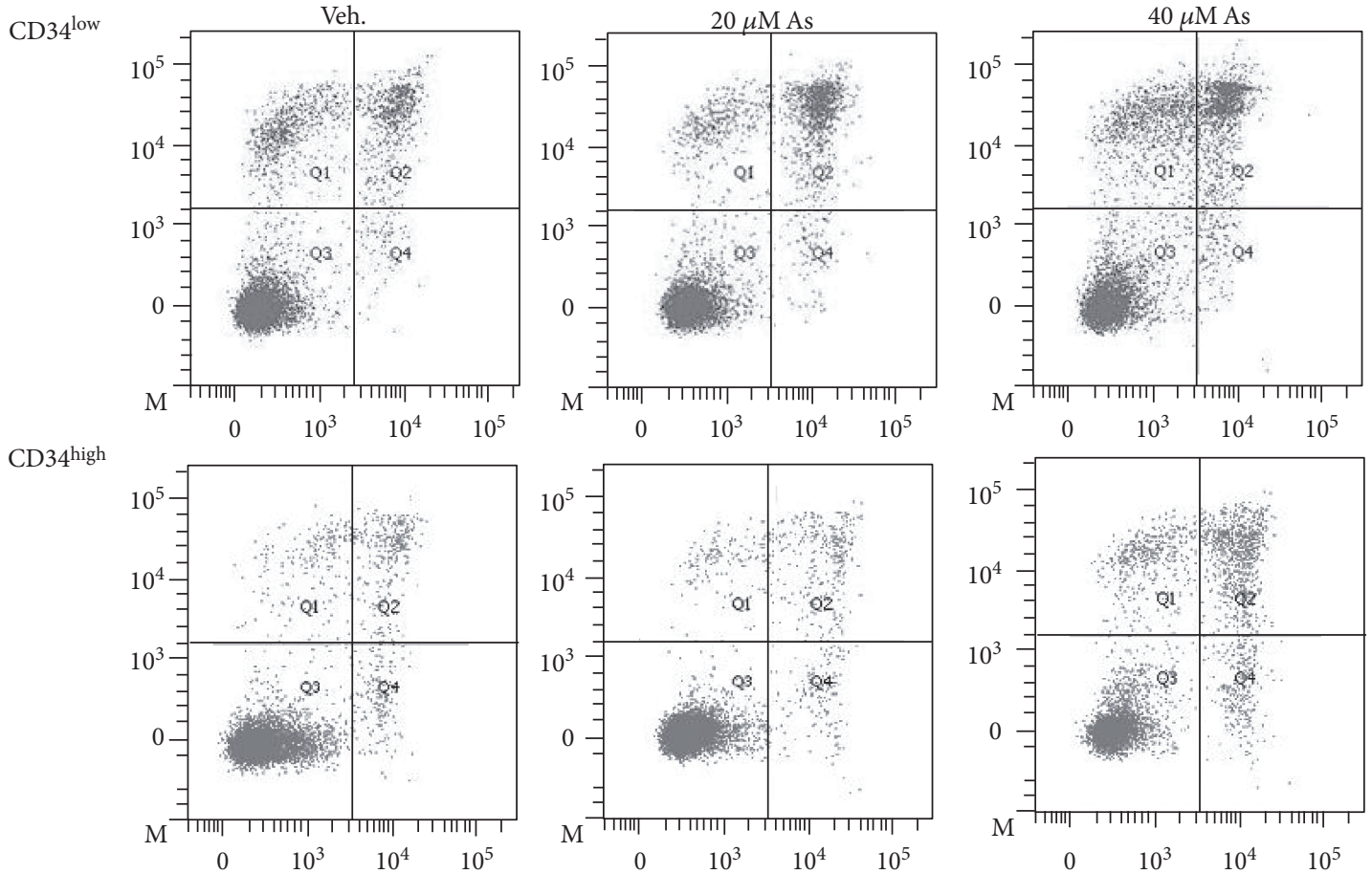

Parent
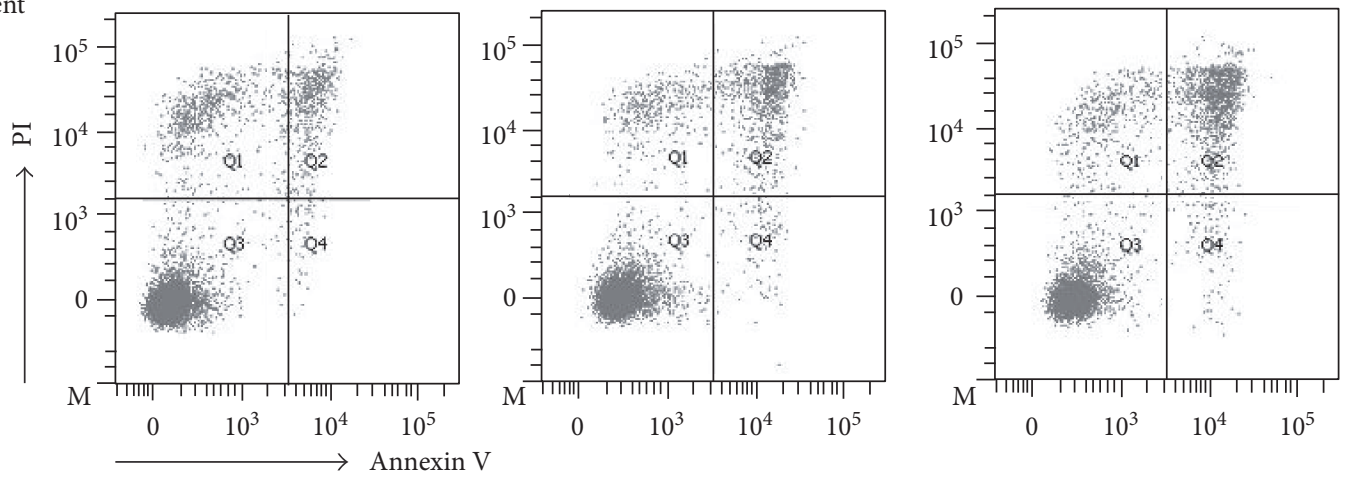

(c)

FIGURE 3: Hyperresistance of CD34 $4^{\text {high }}$-enriched cells to acute arsenic toxicity. (a) Cell viability determined with MTS assay after $24 \mathrm{~h}$ exposure to sodium arsenite. $n=4$. (b) Quantification and (c) representative image for Annexin V-FITC and PI double staining cells determined with flow cytometry. Apoptotic cells after $24 \mathrm{~h}$ exposure to sodium arsenite were counted as the cells in both Q2 and Q4. $n=3$. ${ }^{*} p<0.05$ compared with CD $34{ }^{\text {low }}$-expressing compartment. ${ }^{\#} p<0.05$ compared with parent compartment. 


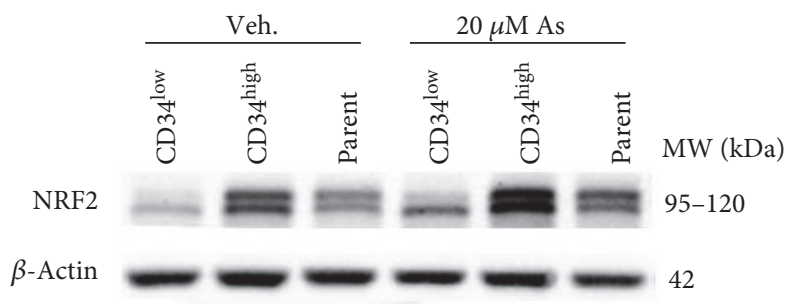

(a)

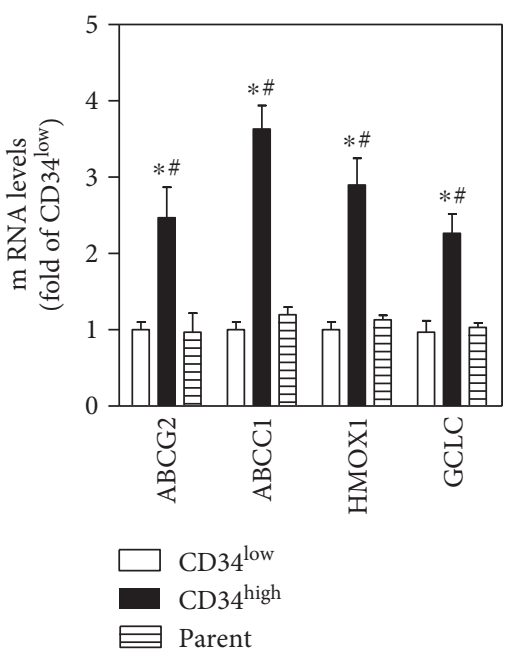

(b)

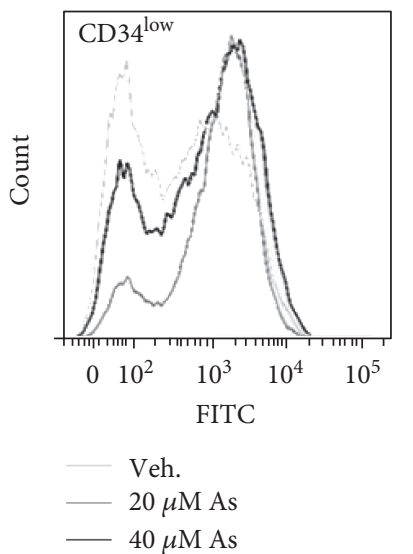

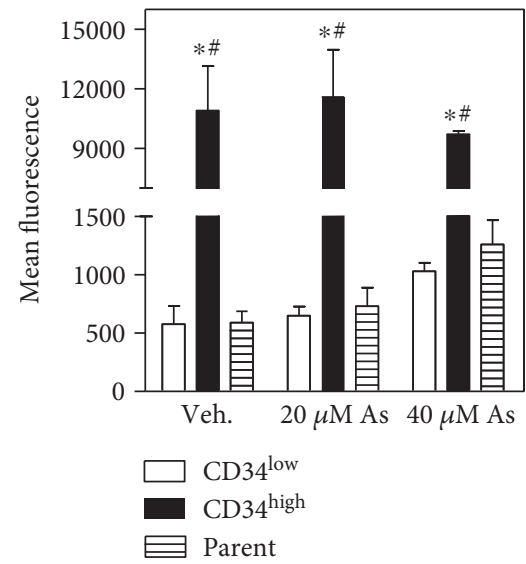

(c)
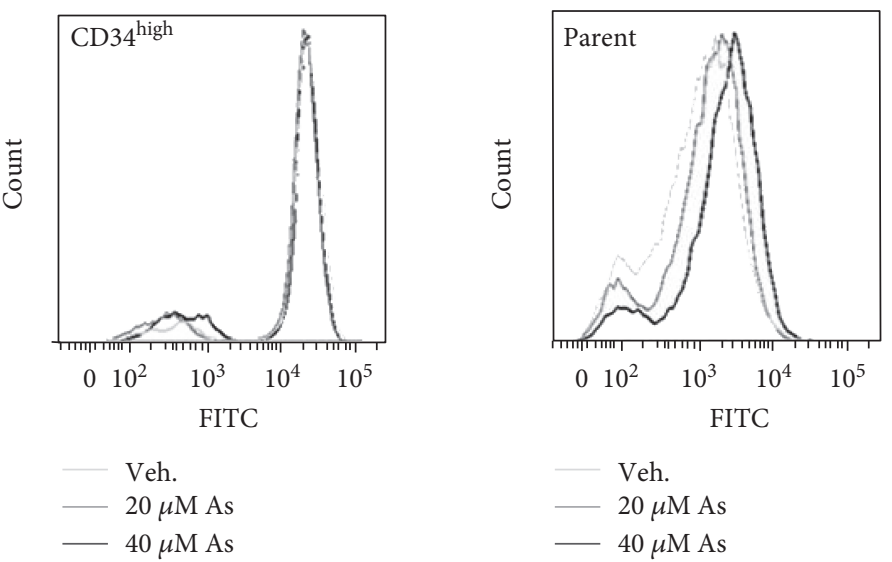

(d)

FIGURE 4: High NRF2 activity and ROS levels in CD34 $4^{\text {high }}$-enriched cells. (a) Representative image of Western blot for NRF2 in CD34 $4^{\text {low }}$ expressing, CD34 ${ }^{\text {high }}$-enriched, and parent cells. Cells were exposed to Veh. or $20 \mu \mathrm{M}$ sodium arsenite for $6 \mathrm{~h}$. (b) Innate mRNA levels of NRF2 downstream genes, including those encoding MRPs and antioxidant-related proteins in CD34 ${ }^{\text {low }}$-expressing, CD34 ${ }^{\text {high }}$-enriched, and parent cells. (c) Quantification and (d) representative histogram for intracellular ROS determined with flow cytometry. Cells were treated with Veh., $20 \mu \mathrm{M}$, or $40 \mu \mathrm{M}$ sodium arsenite for $2 \mathrm{~h} . n=3 .{ }^{*} p<0.05$ compared with CD34 ${ }^{\text {low }}$-expressing compartment. ${ }^{*} p<0.05$ compared with parent compartment.

scramble compartments in response to $10 \mu \mathrm{M}$ to $80 \mu \mathrm{M}$ arsenic, ranging from $9 \%$ to $29 \%$, was observed. (Figure $6(\mathrm{~d})$ ). In addition, NRF2-KD in CD34 $4^{\text {high }}$-enriched cells did not affect the number of holoclones but reduced the size of holoclones compared with scramble (Figure 6(e)). Meanwhile, cells in NRF2-KD holoclones were not as small or as compact as in scramble (Figure 6(e)).

\section{Discussion}

In the present study, we found that $\mathrm{CD} 34^{\text {high }}$-enriched cells purified from the HaCaT cell line exhibited a stem-like phenotype. In addition, the CD $34^{\text {high }}$ stem-like cells showed hyperresistance to arsenic toxicity compared with the mature cells. This hyperresistance was associated with higher innate 


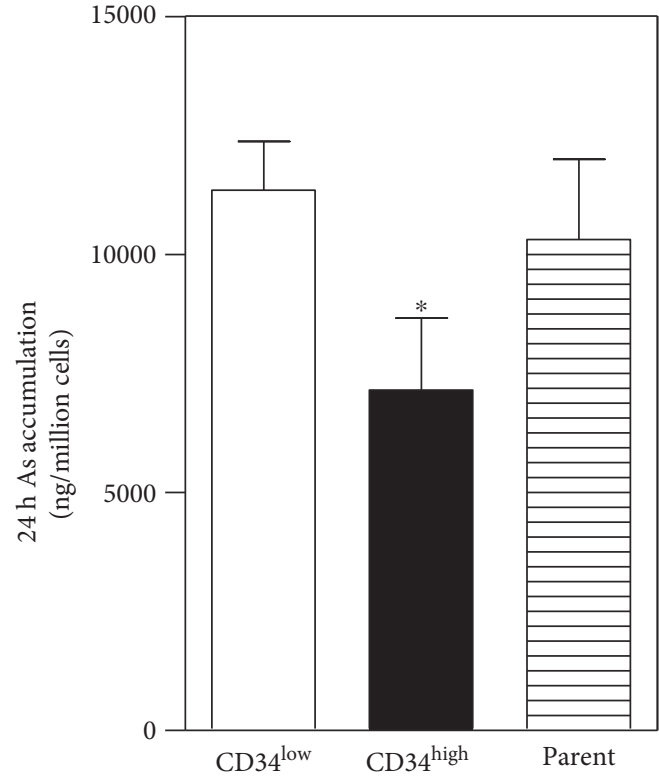

(a)

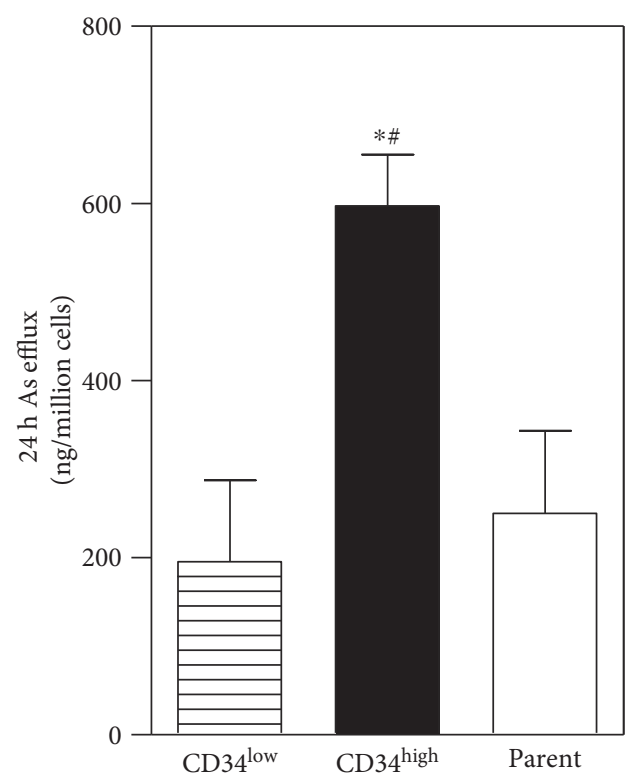

(b)

Figure 5: Accumulation and efflux of arsenic in the CD34 $4^{\text {low }}$-expressing, CD34 $4^{\text {high }}$-enriched, and parent cells. (a) Cellular accumulation of arsenic after $24 \mathrm{~h}$ exposure to $10 \mu \mathrm{M}$ of sodium arsenite. (b) $24 \mathrm{~h}$ cellular efflux of arsenic into the medium. $n=4 .{ }^{*} p<0.05$ compared with the CD $34^{\text {low }}$-expressing cells. ${ }^{\#} p<0.05$ compared with the parent cells.

expression of NRF2 and its downstream genes in CD34 $4^{\text {high }}$ cells. These data support the hypothesis that skin stem/progenitor cells have a survival selection advantage in response to arsenic exposure, which serves as a possible mechanism for the observed overabundance of stem cells during arsenic carcinogenesis [7-9]. Our results are consistent with the previous report by Tokar et al. [27], which found that the WPE human prostate stem cells showed innate resistance and hyperadaptability to arsenic with higher transcript expression of NRF2, ABCC1, and GST-pi than the parent RWPE-1 cells.

Although the role of stem cells in arsenic adaptation is still poorly understood, stem cells are usually resistant to chemical toxicity and act as a "strategic" reserve for wound repair from chemical insult $[26,37]$. Resistance to toxins of stem cells is mostly observed in cancer stem cells and is largely attributed to overexpression of antioxidant proteins and low intracellular levels of reactive oxygen species. As a master transcription factor for antioxidant proteins, NRF2 is likely to account for the toxic-resistance feature of normal stem cells and cancer stem cells [38]. With respect to normal stem cells, exogenous NRF2 transduction or pharmacological NRF2 activation (e.g., tBHQ or melatonin) prevented toxininduced cell death in human or mouse neural stem cells $[30,39,40]$. In rat cardiac stem cells, NRF2 upregulation induced by resveratrol was found to enhance cell survival and improve cardiac function [41]. In murine mesenchymal stem cells, NRF2 upregulation reduced oxidative stressinduced apoptosis and cytotoxicity [42]. A normal human prostate stem cell line, the WPE-stem cell, showed innate resistance to arsenic cytotoxicity and high transcript expression of antiapopototic, antistress, and drug adaption genes including NRF2 [27]. As for cancer stem cells, higher expression or activity of NRF2 has been demonstrated in glioma, lung, esophageal, breast ovarian, and colon stem cells [43-46]. Our study provides the direct evidence that skin stem/progenitor cells preserve high NRF2 activity. The difference in cell viability between scramble and NRF2-KD CD $34^{\text {high }}$-enriched cells ranged from $9 \%$ to $29 \%$, which is relatively mild and indicates that other mechanisms independent of NRF2 are involved in cell resistance to arsenic. However, this difference is close to what we have observed in comparison of cell viability between $\mathrm{CD} 34^{\text {low }}$-expressing and CD $34^{\text {high }}$-enriched cells. Thus, the relatively high NRF2 expression/activity may play a key role in hyperresistance to arsenic of skin stem/progenitor cells than their mature compartments.

NRF2 is considered to facilitate chemical resistance through several mechanisms: (1) upregulating downstream antioxidants and detoxifying enzymes such as GCLC, GCLM, and HOMX1 [47]; (2) inducing MRPs that export chemicals from the cell [18-20]; (3) interacting with antiapoptotic pathway resulting in attenuation of chemicalinduced apoptosis [48]; and (4) enhancing proteasome activity leading to activation of the survival-related pathway [49]. In the present study, a panel of NRF2 downstream genes was highly expressed in CD $34^{\text {high }}$-enriched cells. High transcript levels of GCLC indicate a potential enhanced glutathione (GSH) synthesis. In addition to antioxidant property, GSH mitigates arsenic toxicity by increasing arsenic export through formation of arsenic-GSH complexes [50]. These complexes can be formed either nonenzymatically [51] or enzymatically by GST-pi [52]. GSH also affects arsenic resistance by participating in arsenic methylation through reduction of pentavalent arsenic species to trivalent ones [53]. However, HaCaT cells are arsenic-methylation deficient. MRPs are export pumps in xenobiotic metabolism and 


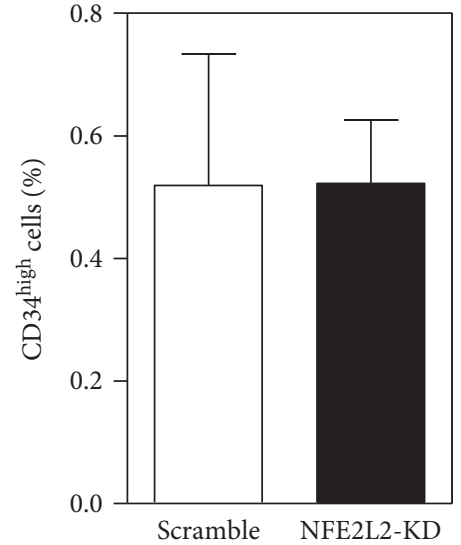

(a)

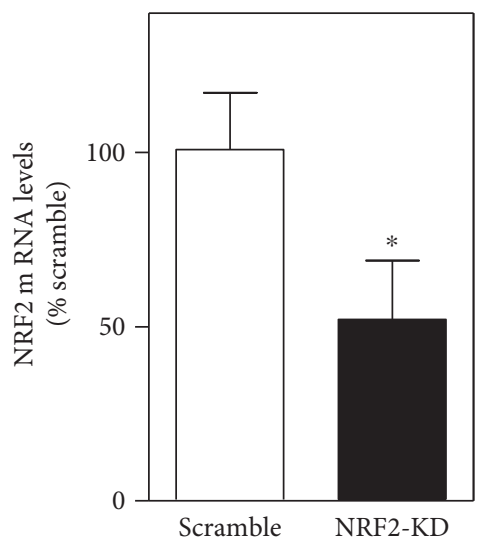

(b)

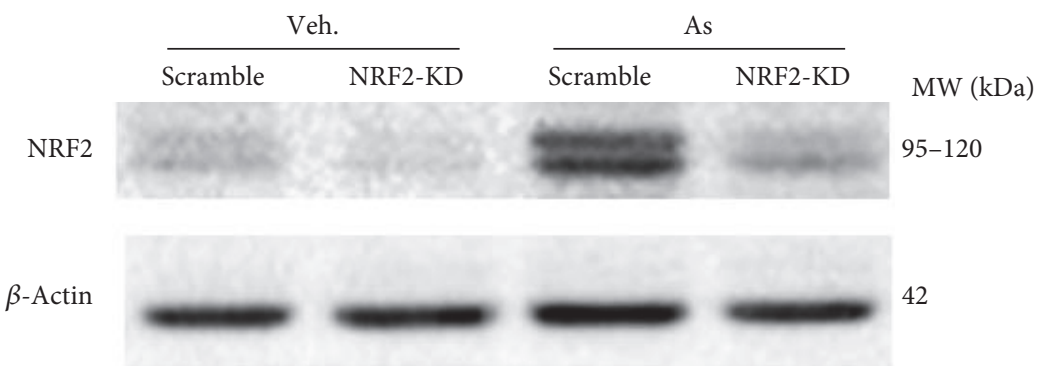

(c)

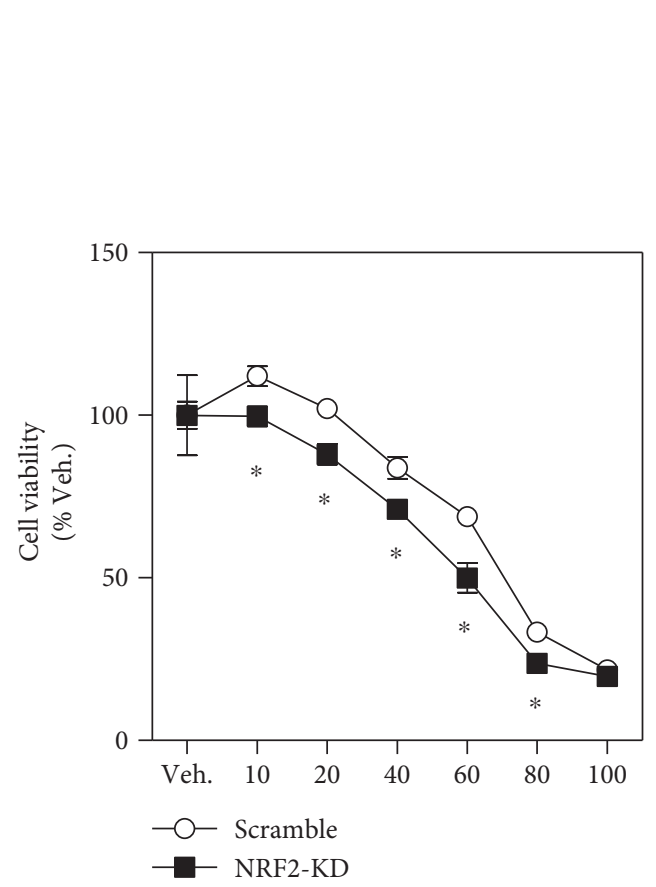

(d)
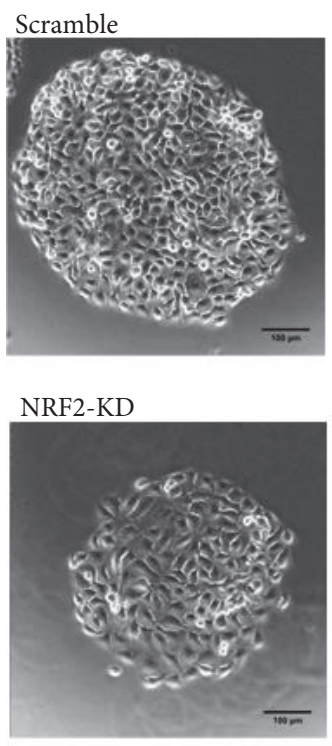

(e)

FIGURE 6: Silencing NRF2 abolished hyperresistance to acute arsenic cytotoxicity and compromised holoclone formation capacity in CD $34^{\text {high }}$-enriched cells. (a) The ratio of CD $34^{\text {high }}$ cells in scramble and NRF2-KD HaCaT cells. $n=3$. (b) mRNA levels of NRF2 determined by RT-qPCR in CD34 ${ }^{\text {high }}$-enriched cells that were purified from scramble and NRF2-KD HaCaT cells. $n=3$. (c) Representative protein bands of NRF2 determined by Western blot in CD34 ${ }^{\text {high }}$-enriched cells that were purified from scramble and NRF2-KD HaCaT cells. Significantly reduced NRF2 protein level was observed in arsenic-treated $(20 \mu \mathrm{M}, 6 \mathrm{~h})$ cells. (d) Cell viability of scramble and NRF2-KD CD34 ${ }^{\text {high }}$-enriched cells determined with MTS assay after $24 \mathrm{~h}$ exposure to sodium arsenite. $n=4$. (e) Holoclones formed by scramble and NRF2-KD CD34 ${ }^{\text {high }}$-enriched cells. Left: representative image of holoclones $(400 \mathrm{x}$ magnification, bar $=100 \mu \mathrm{m})$; right: the average number of holoclones in the $30 \mathrm{~mm}$ dish. $n=5 .{ }^{*} p<0.05$ compared with the scramble compartment. 
showed higher transcript levels in CD34 ${ }^{\text {high }}$-enriched cells. All are consistent with the observed low accumulation but high export of arsenic in CD34 ${ }^{\text {high }}$-enriched cells. Therefore, in addition to the well-known antioxidant activation, elevated arsenic export associated with high NRF2 activity may be involved in hyperresistance to arsenic in CD $34^{\text {high }}$ stem-like cells.

NRF2 also plays an important role in stem cell biology; however, the reports are controversial. The homolog of NRF2 in Drosophila, CncC, was continuously active in intestinal stem cells of Drosophila and maintained quiescence of stem cells [54]. CncC inhibition mediated by KEAP1 was required for proliferation of these stem cells [54]. In human embryonic stem cells (hESCs), NRF2 was highly expressed compared with differentiated cells, while a reduction of NRF2 activity induced cell differentiation and inhibited pluripotency of the stem cells [28]. In human airway basal stem cells, NRF2 activation promoted cell proliferation by regulating NOTCH1 and antioxidant program [55]. In skeletal muscle stem/progenitor cells, NRF2 supported cell proliferation by transcriptional upregulating $M y o D$ and facilitated muscle regeneration [29]. Increased NRF2 activity enhanced both proliferation and differentiation of neuronal progenitor cells [30]. In hematopoietic stem cells (HSCs), NRF2 activation was required for maintenance of quiescence $[56,57]$. Meanwhile, NRF2 activation determined differentiation fate of HSCs, driving the myeloid differentiation but suppressing erythoid or lymphoid differentiation [58]. Though most studies support that NRF2 is involved in pluripotency, proliferation, and differentiation of stem cells, it appears that the exact role of NRF2 in homeostasis of stem/progenitor cells is tissue and cell-type specific. In the present study, NRF2 silencing does not affect population size of stem/progenitor cells under basal conditions. However, NRF2-KD CD $34^{\text {high }}$ enriched cells formed smaller holoclones compared with scramble compartments, indicative of the role of NRF2 in self-renewal in these cells. NRF2 activity is suggested to be closely associated with cell cycle regulation. Cell cycle was arrested in G1 phase in NRF2-knockdown human breast cells with mitoquinone treatment [59]. While G2/M arrest resulted from NRF2 deficiency was observed in mouse alveolar epithelia [60] and human glioma stem cells [61]. Therefore, our data are consistent with previous findings and provide new information on the role of NRF2 in skin stem/ progenitor cells.

Stem cells undergoing self-renewal are indicated to possess low intracellular ROS levels, while elevated ROS levels switch stem cell self-renewal to differentiation [62]. As a potent regulator of stem cell self-renewal and differentiation, NRF2 is suggested to function at least in part due to its antioxidant capacity. However, the functions of NRF2 through regulating ROS in stem cells are diversely reported and presumably context dependent. In some cases, NRF2 may regulate proliferation of stem cells independent upon ROS [56], but directly bind to ARE in promoter region of some stem cell self-renewal genes, such as CXCR4 [57] and NOTCH1 [55]. It is quite interesting to observe that $\mathrm{CD} 34^{\text {high }}$-enriched cells presented with higher NRF2 expression/activity, as well as markedly elevated intracellular ROS levels, than mature compartments under basal conditions. This unexpected high intracellular ROS levels in the putative skin stem-like cells may suggest diverse redox balance in different cell/tissue types and even in cells of the same origin with different differentiating stages. However, the underlying mechanisms cannot be clearly clarified in the present study. Arsenic exposure is well-known to induce enhanced NRF2 protein levels as we have seen in the present study (Figure 4(a)). This NRF2 induction was accompanied with increased ROS levels in the mature compartments $\left(\mathrm{CD} 34^{\text {low }}\right.$-expressing and parent cells), but without alteration of ROS levels in CD $34^{\text {high }}$ enriched cells (Figures 4(c) and 4(d)). One possible explanation for this phenomenon is that innate high expression of NRF2 and antioxidant proteins in CD34 $4^{\text {high }}$-enriched cells veiled the alteration of ROS at the determination time point. Also, arsenic can activate NRF2 through other mechanisms such as NRF2 stabilization by p62-mediated sequestration of KEAP1 resulting from autophagy inhibition [63].

\section{Conflicts of Interest}

The authors declare that they have no conflicts of interest.

\section{Authors' Contributions}

Xiafang $\mathrm{Wu}$ and Bei Yang contributed equally to the work.

\section{Acknowledgments}

This work was supported by the Chinese Nature Science Foundation (81302391, 81573187, and 81602825), Special Foundation for National Outstanding Doctoral Dissertation (201485) from the Ministry of Education, Liaoning Pandeng Scholar Program (to Yuanyuan $\mathrm{Xu}$ ) from the Education Department of Liaoning Province, China, the Program for Liaoning Excellent Talents in University from the Education Department of Liaoning Province, China (LJQ2014090), the Science and Technology Research Program from Education Department of Liaoning Province, China (LK201658), and Excellent Young Scientist Foundation from China Medical University (YQ20160009).

\section{References}

[1] L. Erbanova, M. Novak, D. Fottova, and B. Dousova, "Export of arsenic from forested catchments under easing atmospheric pollution," Environmental Science \& Technology, vol. 42, no. 19, pp. 7187-7192, 2008.

[2] IARC, "IARC monographs on the evaluation of carcinogenic risks to humans," in A Review of Human Carcinogens: Arsenic, Metals, Fibres, and Dusts, IARC, Ed., vol. 100C, pp. 41-48, IARC Press, Leon, France, 2012.

[3] A. H. Smith, G. Marshall, Y. Yuan et al., "Increased mortality from lung cancer and bronchiectasis in young adults after exposure to arsenic in utero and in early childhood," Environmental Health Perspectives, vol. 114, no. 8, pp. 1293-1296, 2006.

[4] T. Yorifuji, T. Tsuda, and P. Grandjean, "Unusual cancer excess after neonatal arsenic exposure from contaminated milk powder," Journal of the National Cancer Institute, vol. 102, no. 5, pp. 360-361, 2010. 
[5] M. P. Waalkes, J. Liu, D. R. Germolec et al., "Arsenic exposure in utero exacerbates skin cancer response in adulthood with contemporaneous distortion of tumor stem cell dynamics," Cancer Research, vol. 68, no. 20, pp. 8278-8285, 2008.

[6] M. P. Waalkes, J. M. Ward, J. Liu, and B. A. Diwan, "Transplacental carcinogenicity of inorganic arsenic in the drinking water: induction of hepatic, ovarian, pulmonary, and adrenal tumors in mice," Toxicology and Applied Pharmacology, vol. 186, no. 1, pp. 7-17, 2003.

[7] Y. Sun, E. J. Tokar, and M. P. Waalkes, "Overabundance of putative cancer stem cells in human skin keratinocyte cells malignantly transformed by arsenic," Toxicological Sciences, vol. 125, no. 1, pp. 20-29, 2012.

[8] E. J. Tokar, B. A. Diwan, and M. P. Waalkes, "Arsenic exposure transforms human epithelial stem/progenitor cells into a cancer stem-like phenotype," Environmental Health Perspectives, vol. 118, no. 1, pp. 108-115, 2010.

[9] Y. Xu, E. J. Tokar, Y. Sun, and M. P. Waalkes, “Arsenictransformed malignant prostate epithelia can convert noncontiguous normal stem cells into an oncogenic phenotype," Environmental Health Perspectives, vol. 120, no. 6, pp. 865$871,2012$.

[10] T. J. Patterson, T. V. Reznikova, M. A. Phillips, and R. H. Rice, "Arsenite maintains germinative state in cultured human epidermal cells," Toxicology and Applied Pharmacology, vol. 207, no. 1, pp. 69-77, 2005.

[11] S. Poojan, S. Kumar, V. Verma, A. Dhasmana, M. Lohani, and M. K. Verma, "Disruption of skin stem cell homeostasis following transplacental arsenicosis; alleviation by combined intake of selenium and curcumin," PLoS One, vol. 10, no. 12, article e0142818, 2015.

[12] J. Kim and Y. S. Keum, "NRF2, a key regulator of antioxidants with two faces towards cancer," Oxidative Medicine and Cellular Longevity, vol. 2016, Article ID 2746457, 7 pages, 2016.

[13] Y. Hou, Y. Wang, H. Wang, and Y. Xu, "Induction of glutathione synthesis in human hepatocytes by acute and chronic arsenic exposure: differential roles of mitogen-activated protein kinases," Toxicology, vol. 325, pp. 96-106, 2014.

[14] J. Pi, B. A. Diwan, Y. Sun et al., "Arsenic-induced malignant transformation of human keratinocytes: involvement of Nrf2," Free Radical Biology \& Medicine, vol. 45, no. 5, pp. 651-658, 2008.

[15] Y. O. Son, P. Pratheeshkumar, R. V. Roy et al., “Antioncogenic and oncogenic properties of Nrf2 in arsenic-induced carcinogenesis," The Journal of Biological Chemistry, vol. 290, no. 45, pp. 27090-27100, 2015.

[16] R. Zhao, B. Yang, L. Wang et al., "Curcumin protects human keratinocytes against inorganic arsenite-induced acute cytotoxicity through an NRF2-dependent mechanism," Oxidative Medicine and Cellular Longevity, vol. 2013, Article ID 412576, 11 pages, 2013.

[17] M. Kobayashi and M. Yamamoto, "Nrf2-Keap1 regulation of cellular defense mechanisms against electrophiles and reactive oxygen species," Advances in Enzyme Regulation, vol. 46, pp. 113-140, 2006.

[18] A. Hayashi, H. Suzuki, K. Itoh, M. Yamamoto, and Y. Sugiyama, "Transcription factor Nrf2 is required for the constitutive and inducible expression of multidrug resistanceassociated protein 1 in mouse embryo fibroblasts," Biochemical and Biophysical Research Communications, vol. 310, no. 3, pp. 824-829, 2003.
[19] A. Singh, H. Wu, P. Zhang, C. Happel, J. Ma, and S. Biswal, "Expression of ABCG2 (BCRP) is regulated by Nrf2 in cancer cells that confers side population and chemoresistance phenotype," Molecular Cancer Therapeutics, vol. 9, no. 8, pp. 23652376, 2010.

[20] X. Wang, C. R. Campos, J. C. Peart et al., "Nrf2 upregulates ATP binding cassette transporter expression and activity at the blood-brain and blood-spinal cord barriers," The Journal of Neuroscience, vol. 34, no. 25, pp. 8585-8593, 2014.

[21] K. Chan, X. D. Han, and Y. W. Kan, "An important function of Nrf2 in combating oxidative stress: detoxification of acetaminophen," Proceedings of the National Academy of Sciences of the United States of America, vol. 98, no. 8, pp. 4611-4616, 2001.

[22] M. Ramos-Gomez, M. K. Kwak, P. M. Dolan et al., "Sensitivity to carcinogenesis is increased and chemoprotective efficacy of enzyme inducers is lost in nrf2 transcription factor-deficient mice," Proceedings of the National Academy of Sciences of the United States of America, vol. 98, no. 6, pp. 3410-3415, 2001.

[23] B. Padmanabhan, K. I. Tong, T. Ohta et al., "Structural basis for defects of Keap1 activity provoked by its point mutations in lung cancer," Molecular Cell, vol. 21, no. 5, pp. 689-700, 2006.

[24] L. M. Solis, C. Behrens, W. Dong et al., "Nrf2 and Keap1 abnormalities in non-small cell lung carcinoma and association with clinicopathologic features," Clinical Cancer Research, vol. 16, no. 14, pp. 3743-3753, 2010.

[25] S. Sukumari-Ramesh, N. Prasad, C. H. Alleyne, J. R. Vender, and K. M. Dhandapani, "Overexpression of Nrf2 attenuates Carmustine-induced cytotoxicity in U87MG human glioma cells," BMC Cancer, vol. 15, p. 118, 2015.

[26] V. S. Donnenberg, J. D. Luketich, R. J. Landreneau, J. A. DeLoia, P. Basse, and A. D. Donnenberg, "Tumorigenic epithelial stem cells and their normal counterparts," Ernst Schering Foundation Symposium Proceedings, vol. 5, pp. 245-263, 2006.

[27] E. J. Tokar, W. Qu, J. Liu et al., "Arsenic-specific stem cell selection during malignant transformation," Journal of the National Cancer Institute, vol. 102, no. 9, pp. 638-649, 2010.

[28] J. Jang, Y. Wang, H. S. Kim, M. A. Lalli, and K. S. Kosik, "Nrf2, a regulator of the proteasome, controls self-renewal and pluripotency in human embryonic stem cells," Stem Cells, vol. 32, no. 10, pp. 2616-2625, 2014.

[29] O. Al-Sawaf, A. Fragoulis, C. Rosen et al., "Nrf2 augments skeletal muscle regeneration after ischaemia-reperfusion injury," The Journal of Pathology, vol. 234, no. 4, pp. 538-547, 2014.

[30] V. Karkkainen, Y. Pomeshchik, E. Savchenko et al., "Nrf2 regulates neurogenesis and protects neural progenitor cells against Abeta toxicity," Stem Cells, vol. 32, no. 7, pp. 19041916, 2014.

[31] I. Malanchi, H. Peinado, D. Kassen et al., "Cutaneous cancer stem cell maintenance is dependent on beta-catenin signalling," Nature, vol. 452, no. 7187, pp. 650-653, 2008.

[32] C. S. Trempus, R. J. Morris, C. D. Bortner et al., "Enrichment for living murine keratinocytes from the hair follicle bulge with the cell surface marker CD34," The Journal of Investigative Dermatology, vol. 120, no. 4, pp. 501-511, 2003.

[33] H. Li, X. Chen, T. Calhoun-Davis, K. Claypool, and D. G. Tang, "PC3 human prostate carcinoma cell holoclones contain self-renewing tumor-initiating cells," Cancer Research, vol. 68, no. 6, pp. 1820-1825, 2008.

[34] Y. Xu, H. Wang, Y. Wang, Y. Zheng, and G. Sun, "Effects of folate on arsenic toxicity in Chang human hepatocytes: 
involvement of folate antioxidant properties," Toxicology Letters, vol. 195, no. 1, pp. 44-50, 2010.

[35] E. M. Brambila, W. E. Achanzar, W. Qu, M. M. Webber, and M. P. Waalkes, "Chronic arsenic-exposed human prostate epithelial cells exhibit stable arsenic tolerance: mechanistic implications of altered cellular glutathione and glutathione S-transferase," Toxicology and Applied Pharmacology, vol. 183, no. 2, pp. 99-107, 2002.

[36] R. Zhao, Y. Hou, P. Xue et al., "Long isoforms of NRF1 contribute to arsenic-induced antioxidant response in human keratinocytes," Environmental Health Perspectives, vol. 119, no. 1, pp. 56-62, 2011.

[37] V. S. Donnenberg, R. J. Landreneau, and A. D. Donnenberg, "Tumorigenic stem and progenitor cells: implications for the therapeutic index of anti-cancer agents," Journal of Controlled Release, vol. 122, no. 3, pp. 385-391, 2007.

[38] I. G. Ryoo, S. H. Lee, and M. K. Kwak, "Redox modulating NRF2: a potential mediator of cancer stem cell resistance," Oxidative Medicine and Cellular Longevity, vol. 2016, Article ID 2428153, 14 pages, 2016.

[39] J. Li, D. Johnson, M. Calkins, L. Wright, C. Svendsen, and J. Johnson, "Stabilization of Nrf2 by tBHQ confers protection against oxidative stress-induced cell death in human neural stem cells," Toxicological Sciences, vol. 83, no. 2, pp. 313-328, 2005.

[40] J. Song, S. M. Kang, K. M. Lee, and J. E. Lee, "The protective effect of melatonin on neural stem cell against LPS-induced inflammation," BioMed Research International, vol. 2015, Article ID 854359, 13 pages, 2015.

[41] N. Gurusamy, D. Ray, I. Lekli, and D. K. Das, "Red wine antioxidant resveratrol-modified cardiac stem cells regenerate infarcted myocardium," Journal of Cellular and Molecular Medicine, vol. 14, no. 9, pp. 2235-2239, 2010.

[42] M. Mohammadzadeh, R. Halabian, A. Gharehbaghian et al., "Nrf-2 overexpression in mesenchymal stem cells reduces oxidative stress-induced apoptosis and cytotoxicity," Cell Stress \& Chaperones, vol. 17, no. 5, pp. 553-565, 2012.

[43] C. A. Del Vecchio, Y. Feng, E. S. Sokol et al., "De-differentiation confers multidrug resistance via noncanonical PERK-Nrf2 signaling," PLoS Biology, vol. 12, no. 9, article e1001945, 2014.

[44] E. Singer, J. Judkins, N. Salomonis et al., "Reactive oxygen species-mediated therapeutic response and resistance in glioblastoma," Cell Death \& Disease, vol. 6, article e1601, 2015.

[45] B. Yang, Y. F. Ma, and Y. Liu, "Elevated expression of Nrf-2 and ABCG2 involved in multi-drug resistance of lung cancer SP cells," Drug Res (Stuttg), vol. 65, no. 10, pp. 526-531, 2015.

[46] M. Zhang, A. Mathur, Y. Zhang et al., "Mithramycin represses basal and cigarette smoke-induced expression of ABCG2 and inhibits stem cell signaling in lung and esophageal cancer cells," Cancer Research, vol. 72, no. 16, pp. 4178-4192, 2012.

[47] K. A. Jung and M. K. Kwak, "The Nrf2 system as a potential target for the development of indirect antioxidants," Molecules, vol. 15, no. 10, pp. 7266-7291, 2010.

[48] S. K. Niture and A. K. Jaiswal, "Inhibitor of Nrf2 (INrf2 or Keap1) protein degrades Bcl-xL via phosphoglycerate mutase 5 and controls cellular apoptosis," The Journal of Biological Chemistry, vol. 286, no. 52, pp. 44542-44556, 2011.

[49] A. Arlt, I. Bauer, C. Schafmayer et al., "Increased proteasome subunit protein expression and proteasome activity in colon cancer relate to an enhanced activation of nuclear factor E2-related factor 2 (Nrf2)," Oncogene, vol. 28, no. 45, pp. 3983-3996, 2009.

[50] Z. Gregus and A. Gyurasics, "Role of glutathione in the biliary excretion of the arsenical drugs trimelarsan and melarsoprol," Biochemical Pharmacology, vol. 59, no. 11, pp. 1375-1385, 2000.

[51] N. Scott, K. M. Hatlelid, M. K. NE, and D. E. Carter, "Reactions of arsenic(III) and arsenic(V) species with glutathione," Chemical Research in Toxicology, vol. 6, no. 1, pp. 102-106, 1993.

[52] J. Liu, H. Chen, D. S. Miller et al., "Overexpression of glutathione S-transferase II and multidrug resistance transport proteins is associated with acquired tolerance to inorganic arsenic," Molecular Pharmacology, vol. 60, no. 2, pp. 302 309, 2001.

[53] K. T. Kitchin, "Recent advances in arsenic carcinogenesis: modes of action, animal model systems, and methylated arsenic metabolites," Toxicology and Applied Pharmacology, vol. 172, no. 3, pp. 249-261, 2001.

[54] C. E. Hochmuth, B. Biteau, D. Bohmann, and H. Jasper, "Redox regulation by Keap1 and Nrf2 controls intestinal stem cell proliferation in Drosophila," Cell Stem Cell, vol. 8, no. 2, pp. 188-199, 2011.

[55] M. K. Paul, B. Bisht, D. O. Darmawan et al., "Dynamic changes in intracellular ROS levels regulate airway basal stem cell homeostasis through Nrf2-dependent Notch signaling," Cell Stem Cell, vol. 15, no. 2, pp. 199-214, 2014.

[56] A. A. Merchant, B. Bisht, D. O. Darmawan et al., "The redoxsensitive transcription factor Nrf2 regulates murine hematopoietic stem cell survival independently of ROS levels," Blood, vol. 118, no. 25, pp. 6572-6579, 2011.

[57] J. J. Tsai, J. A. Dudakov, K. Takahashi et al., "Nrf2 regulates haematopoietic stem cell function," Nature Cell Biology, vol. 15, no. 3, pp. 309-316, 2013.

[58] S. Murakami, R. Shimizu, P. H. Romeo, M. Yamamoto, and H. Motohashi, "Keap1-Nrf2 system regulates cell fate determination of hematopoietic stem cells," Genes to Cells, vol. 19, no. 3, pp. 239-253, 2014.

[59] V. A. Rao, S. R. Klein, S. J. Bonar et al., "The antioxidant transcription factor Nrf2 negatively regulates autophagy and growth arrest induced by the anticancer redox agent mitoquinone," The Journal of Biological Chemistry, vol. 285, no. 45, pp. 34447-34459, 2010.

[60] N. M. Reddy, S. R. Kleeberger, J. H. Bream et al., "Genetic disruption of the Nrf2 compromises cell-cycle progression by impairing GSH-induced redox signaling," Oncogene, vol. 27, no. 44, pp. 5821-5832, 2008.

[61] J. Zhu, H. Wang, Q. Sun et al., "Nrf2 is required to maintain the self-renewal of glioma stem cells," BMC Cancer, vol. 13, article 23937621, p. 380, 2013.

[62] K. Wang, T. Zhang, Q. Dong, E. C. Nice, C. Huang, and Y. Wei, "Redox homeostasis: the linchpin in stem cell self-renewal and differentiation," Cell Death \& Disease, vol. 4, article e537, 2013.

[63] A. Lau, Y. Zheng, S. Tao et al., "Arsenic inhibits autophagic flux, activating the Nrf2-Keap1 pathway in a p62-dependent manner," Molecular and Cellular Biology, vol. 33, no. 12, pp. 2436-2446, 2013. 


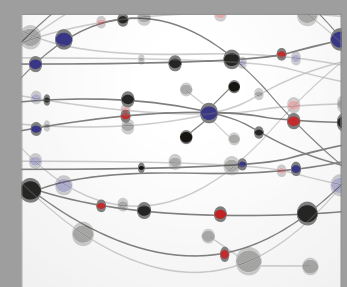

The Scientific World Journal
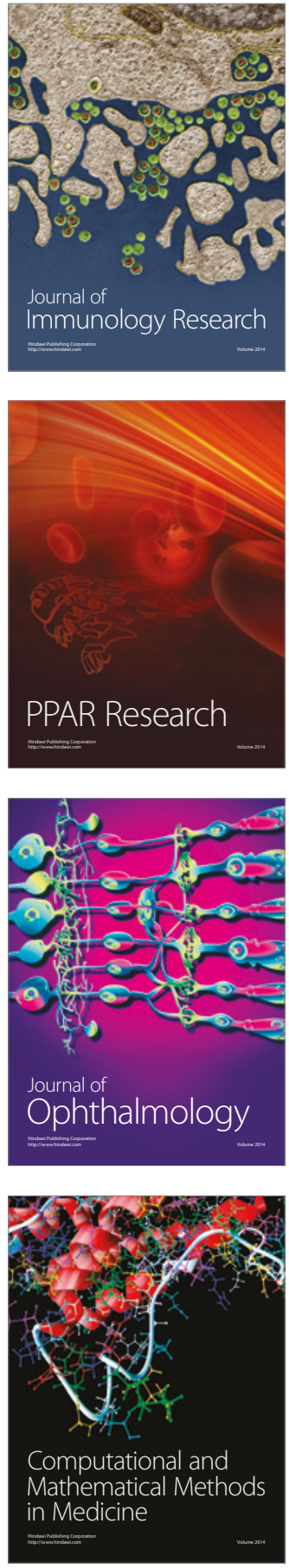

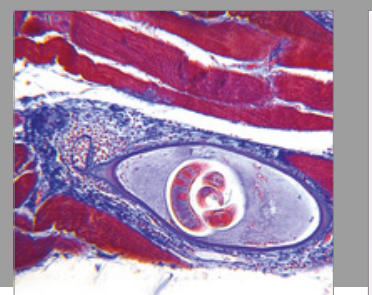

Gastroenterology Research and Practice
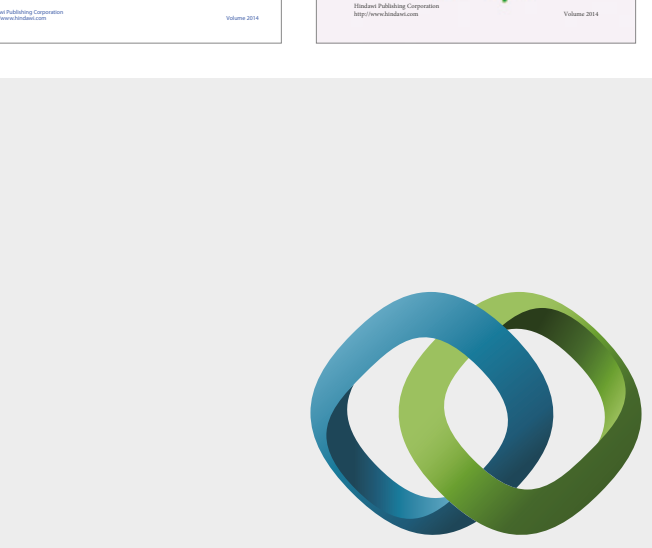

\section{Hindawi}

Submit your manuscripts at

https://www.hindawi.com
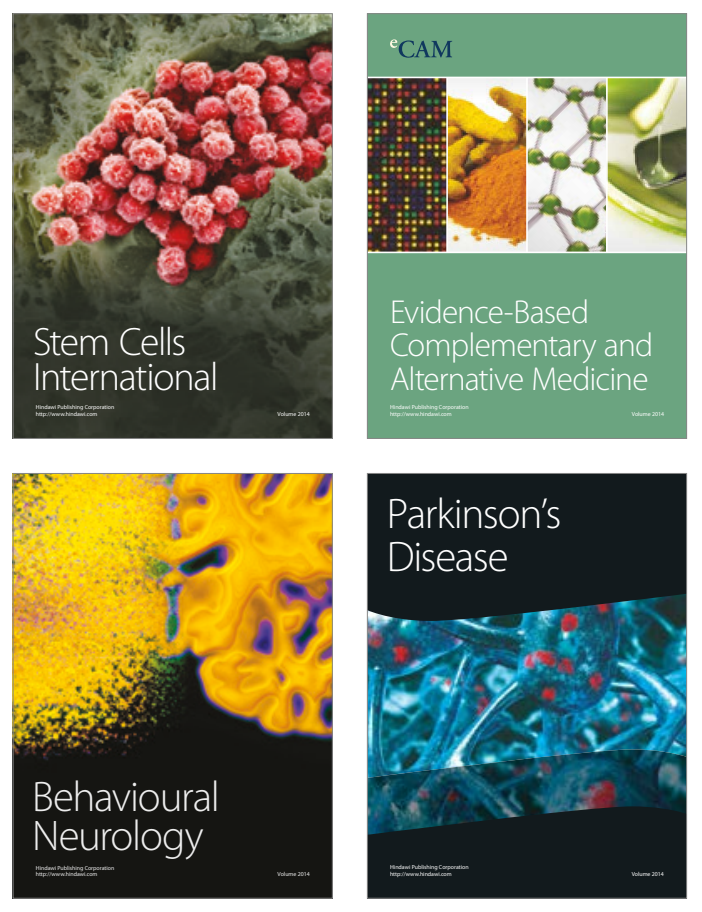
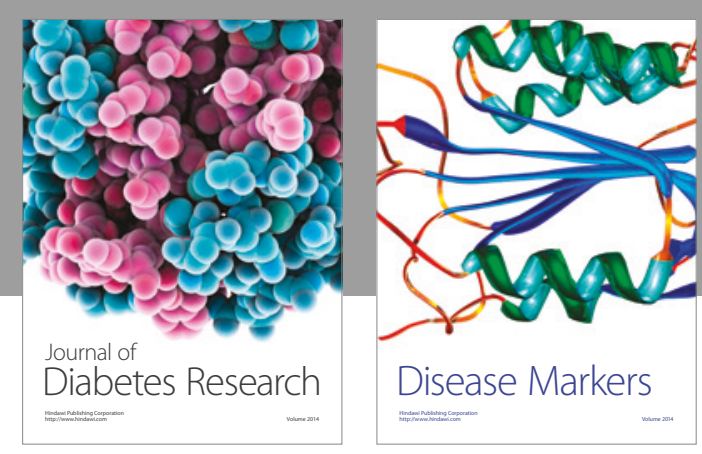

Disease Markers
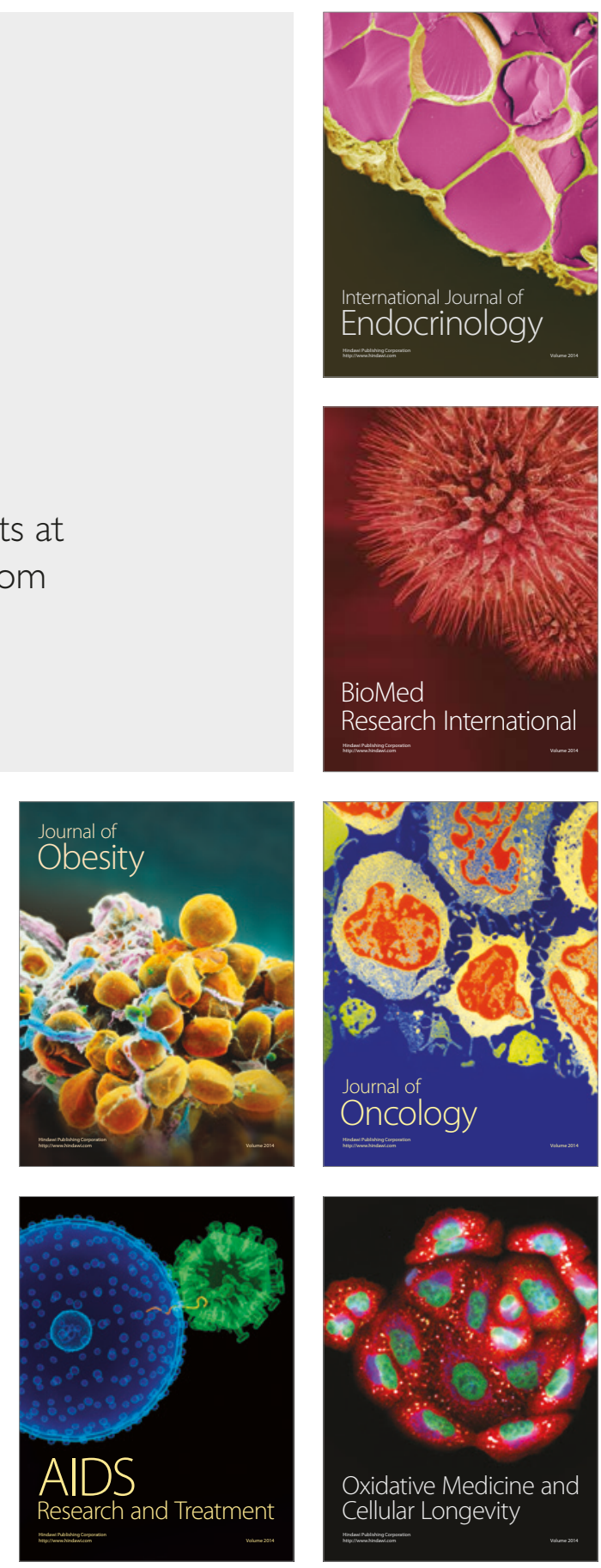